\title{
Fontys valg
}

\author{
Ny tysk litteratur mellem regionalisme og internationalisme
}

\author{
Steen Klitg̊̊rd Povlsen
}

Man kan ofte i Tyskland møde den - typisk lidt spøgefuldt fremsatte - påstand, at globalisering er noget tyskere har et særligt forhold til, og at det derfor ikke er nogen tilfældighed, at en af de vigtigste teoretikere inden for dette felt er tysker. ${ }^{\text {T }}$ Tyskere er vant til, hævder man, at lade deres nationale identitet opgå $\mathrm{i}$ en større helhed, sådan som det skete omkring den tyske rigsdannelse 1870 ; og millioner af etniske tyskere har altid levet $\mathrm{i}$ grænseområder $\mathrm{i}$ eller ind mod andre nationaliteter og er om nogen vante til multikulturel sameksistens (selv om man selvfølgelig indrømmer, at det ikke altid har været problemfrit!). Og her på det sidste har man igen været igennem en proces, hvor to meget forskellige dele af Tyskland har skullet smelte sammen til én, konføderal enhed. Det har bestemt ikke været uden vanskeligheder, men det giver øvelse, fremhæver man. Intetsteds i Europa er tilslutningen til EU så stor som i Tyskland, få steder finder man en sådan parathed til at indgå og opgå i transnationale fællesskaber, også selv om det koster. Få steder tænker man så globalt som i Tyskland - hævder tyskerne.

Men det er også få steder i verden, at man tænker så regionalt som i Tyskland. Selv om flertallet af tyskere $\mathrm{i}$ dag, som alle andre europæere, lever i storbyer, føler man sig stadig tæt forbundet med den egn, man selv eller familien stammer fra. $\mathrm{Og}$ selv de store byer forstår sig selv i deres regionale forskellighed fra de andre storbyer: Münchens største fodboldklub hedder Bayern og Hamburg fastholder i sit officielle navn tilknytningen til Hansaen og det baltiske rum. Köln er rhinlandsk og Berlin preussisk, selv om lige netop den sidste identitet i særlig grad er i skred i disse år, hvor denne by er ved at vokse sammen af sine to halvdele og transformere sig til
Tysklands administrative og kulturelle hovedstad. Men få steder i verden dækker ellers Roland Robertsons begreb 'glokal' så godt som i Tyskland: et verdens-vendt folk med en intens interesse for deres hjemstavns særegenhed. Omrejsende som ingen andre, men altid med hjembyen og -egnen i bagagen.

Det er ikke mærkeligt, at den nye tyske litteratur har spejlet denne dobbeltidentitet og har været med til at give den form og stemme. Det er ikke i dag muligt at skrive en tysk litteraturhistorie med udgangspunkt $\mathrm{i}$ regionerne, sådan som det har været tilfældet helt op i moderne tid. ${ }^{2}$ Men det glokale perspektiv er fremtrædende i meget af den litteratur, der skrives aktuelt i Tyskland, og det bliver ikke mindst tydeligt, når det drejer sig om behandlingen af det mest påtrængende tyske identitetsproblem i dag: sammenlægningen af Øst- og Vesttyskland. Derom handler det følgende.

Fontys valg

Lad os da passende begynde med tysk litteraturs store gamle mand. I en af de største og, tør man vel hævde, til dato bedste romaner om den tyske genforening er hovedpersonen modstander af samme. Theodor Wuttke, kaldet Fonty på grund af hans beundring for og viden om den tyske I80o-tals forfatter Theodor Fontane, i Ein weites Feld (1995) deler naturligvis ikke $i$ et og alt synspunkter og da slet ikke skæbne med sin forfatter, Günter Grass, men Grass trådte i artikler og taler omkring genforeningen frem med tanker, der på dette punkt meget lignede Fontys. ${ }^{3}$ Fonty har klaret sig igennem nazi- og DDR-tid, men genforeningens grådige opslugen af det østlige Tyskland og dens oppustede retorik har han svært ved at klare: via mere eller mindre direkte 
Fontane-citater hævder han, at det altid har ligget $\mathrm{i}$ det tyske (preussiske) væsen at spalte alt i småstykker, også den nationale enhed: "Men tyskerne - når der viser sig et eller andet, går de straks fra hinanden igen i to dele", proklamerer han.4 Ikke alene tyskernes egenart og tradition, men også hensynet til det omgivende Europa tilsiger ifølge Fonty, at Tyskland bør forbliver delt: "I Tyskland har enheden altid spoleret demokratiet" får han lejlighed til at udslynge over mængden ved den skelsættende demonstration på Alexanderplatz i Berlin d. 4. november 1989.5 Øjensynligt som en slags imaginær stedfortræder for sin forfatter, der ikke kom til orde ved den begivenhed.

Set i bakspejlet virker Fontys (og Günter Grass') bekymringer ved den lejlighed noget overdrevne. Selv om vi alle kan forskrækkes over nynazisternes indtog $\mathrm{i}$ østtyske delstatsparlamenter og undre os over visse tyske politiske kredses demokratiopfattelse, når de harcellerer over, at et nationalt mindretalsparti bruger sine mandater til at føre politik med, så er der ingen, der i dag med rimelighed kan hævde, at det fællestyske demokrati ikke er solidt grundfæstet. Heller ikke, at Tyskland ikke skulle være en konstruktiv og fredelig samarbejdspartner for de øvrige europæiske lande. Tyskland er i dag lige så 'normalt' et land, som de fleste af dets indbyggere i øst og vest har ønsket det siden Murens fald. Med 'normale' problemer.

Sådan som Fontys franske barnebarn, Madeleine, ønsker sig det. Madeleine er det illegitime resultat af Fontys indsats som soldat under 2. verdenskrig, og hun opsøger sin bedstefar både af personlige og politiske grunde. Hun tror nemlig på det fælleseuropæiske projekt med Tyskland som en vigtig medspiller: “Uden et stærkt Tyskland falder Frankrig i søvn”, er hendes argument. ${ }^{6}$ Hun er ikke bange for et forenet Tyskland. Og det er hos hende med de internationalistiske og troskistiske opfattelser, at Fonty ender til sidst, da han ikke kan holde stemningen ud i det af privatiseringsanstalten Treuhand hærgede Berlin. Selv om Tyskland og Frankrig hører sammen, er der trods alt ingen fare for, at de vokser sammen.

Før Fonty forsvinder og dukker op igen i Frankrig, har der imidlertid vist sig en anden mulighed for at undslippe det forenede Tysklands påtrængende magt. Hans trofaste følgesvend, den evige hemmelige agent, Hoftaller, forhindrer ham ganske vist tidligere i romanen i at flygte til England, hvor Fontys forbillede, Theodor Fontane, mente at finde sit utopia, men opridser ved den lejlighed et andet perspektiv for hans fortsatte virke $\mathrm{i}$ det forenede Tyskland:

På vegne af Treuhandanstalt skal De sammen med interesserede investorer besigtige tidligere slotte og herregårde. En rundrejse hertil, en anden dertil. Man sætter sin lid til Deres sagkyndige omvisning. De folk fra Treuhand ved, at De er velkendt med alting dér helt ud i den fjerneste krog. Det skal blive en slags genoplivelse af vandreturene gennem Mark Brandenburg... Det er da noget, Fonty! Det er der fremtid i. Af sted, ud i landskabet! Ikke London, men Kossenblatt Slot står på programmet. Ture i Spreewald, til det ruppinske Schweiz, Havel-svaner, fyrreskove, vilde og plejede. Og alle vegne en masse spøgelses- og rædselshistorier. De får lov at rejse, Fonty, fra slot til slot!?

Det er et meget fristende perspektiv, Hoftaller her opsætter for Fonty, for det appelerer stærkt til hans regionalisme, hans intense beskæftigelse med hjemstavnen - en interesse han (selvfølgelig) deler med forbilledet Fontane, til hvis Wanderungen durch die Mark Brandenburg Hoftaller her henviser. Både som soldat i Frankrig og som borger i DDR overlevede Fonty tyranniet ved at dykke ned i det lokale og finde de historier og anekdoter, der befandt sig dér. Når han siger nej til Hoftallers tilbud, skyldes det, at nu skal han fortælle om sin egn for at sælge den til rige vesttyskere. Så foretrækker han det trotskistiske Frankrig.

Fontanes Wanderungen durch die Mark Brandenburg er udgivet $i$ årene I862-I882, da Berlin bliver hovedstad i et forenet Tyskland, og den nærliggende storby fungerer gennem hele værket som et stadigt referencepunkt for lovprisningen af de landlige herligheder. Fontane er hele tiden klar over de sociale spændinger, som hans egn indeholder, men så slemme som i Berlin er de dog ikke. Værket er på denne måde et eksempel på den erkendelse, Raymond Williams beskriver i sit værk The Country and the City (1973): 
landskabet, hjemegnen bliver først et ideal, når det er ved at blive tabt. Tendensen til fordybelse $\mathrm{i}$ det lokale er ikke et specielt tysk fænomen, selv om det tyske sprog har måttet lægge navn til begrebet Blut und Boden; men den regionale forankring har måske særligt stærke traditioner $i$ et Tyskland, hvor et mylder af småstater først sent blev samlet i ét rige. Det er en hyppigt forekommende iagttagelse, at tyskerne føler sig mere forbundne med deres egn end med deres land. Bernhard Schlink beskriver det i sit essay Heimat als Utopie fra 2000 således: En amerikansk journalist rejste i I970 gennem Forbundsrepublikken,

[...] og beskrev, hvordan folk i Baden-Würtenberg fortalte ham om den badisk-elsassisk-schweitsiske region i Oberrhein-området og om, at de snarere var øvrerhinsk-europæiske regionalister end tyskere, og Hamborgerne om, at de som hanseater var mere maritimt og britisk orienterede end tysk... osv $[\ldots]$ osv $^{8}$

Schlink beretter også, hvordan hans egen generation (han er født I944) efter krigen opfattede al tale om den tyske nation med mistro og i stedet forbandt sig med begrebet 'eksil' indre som ydre - som udtryk for frihed, tolerance og åbenhed. 9 Tysker var man ikke, kun rhinlænder, bayerer eller sachser.

Hvad der hører sammen...

Det samme gjalt for den østtyske befolkning, da man efter I990 skulle til at vænne sig til at være del af et fælles Tyskland. DDR havde naturligvis kun meget få identificeret sig med, men som journalisten og romanforfatteren Peter Richter skriver i sin Blühende Landschaften. Eine Heimatkunde fra 2004: tysker kunne man heller ikke bekvemme sig til at kalde sig (selv om mange op til Murens fald havde råbt: 'Wir sind ein Volk'), og så valgte man det lokale. Til sin store forbavselse opdagede han selv, der var fra Dresden, at han begyndte at kalde sig sachser. Senere fandt han og mange andre tidligere østtyskere ud af, at genforeningen havde givet dem en følelse af at være noget særligt, regionalt: netop østtyskere. Det er det, Peter Richter kalder “østtyskernes fødsel via genforeningen". Io I samme forbindelse refererer han tyske socialforskere for at fastslå, at identifikationen med Forbundsrepublikken Tyskland er aftaget siden genforeningen. ${ }^{\text {II }}$ Det er som om tyskerne reagerer som Fonty: jo større, jo værre.

Günter Grass satte i sin store genforeningsroman sin hovedperson Fonty over for valget mellem et 'indre eksil' i form af rundvisningsture i Mark Brandenburg for pengestærke vesttyskere - eller flugt til Frankrig. Han valgte det sidste. Rejser man i de fem nye forbundslande eller læser beretninger derfra, får man imidlertid indtryk af, at ikke alle har valgt som Fonty. Peter Richter beskriver i sin erindringsbog, hvor han i øvrigt omtaler sig selv som læserens "Wanderleiter" I2 gennem det genforenede Tyskland, hvordan det tidligere DDR har forvandlet sig til en blanding af amerikansk landskab og en kitschet middelalderkulisse med det formål at hente penge ud af vesttyske turister: "Som om fortiden var det væsentligste og nutiden stod i stadig fare for at blive kompromiteret". ${ }^{13}$ Mange østtyskere har gjort en dyd af nødvendigheden og gjort det tilbagestående til en levevej. Hvad Fonty ikke ville, har andre gjort, og mange vesttyskere har opkøbt østtysk ejendom og istandsat ruinerne. Titelhistorien i Judith Hermanns bestseller-novellesamling Sommerhus, senere fra 1998 giver en traurig variant af denne tilbage-til-østendrøm.

Men Peter Richters bog er også et eksempel på en mere seriøs udgave af den østtyske selvbesindelse, som genforeningen har udløst. En af de mange unge, tyske forfattertalenter, som Günter Grass har taget hånd om og befordret, Ingo Schulze, ${ }^{\mathrm{I}}$ gav allerede i Simple Stories. Roman fra den østtyske provins (I998) et komplekst og kompakt billede af byen Altenburg syd for Leipzig, en skildring der i sin neutralitet og faktuelle iagttagelse af overgangens mønstre på fornem vis tolkede en amerikansk tradition fra Edgar Lee Masters, Hemingway og Sherwood Anderson til Raymond Carver. Ingo Schulze satte pludselig den østtyske søgen efter en identitet ind i en verdenslitterær sammenhæng, gjorde det der skete i Altenburg til en del af en global problemstilling.

Schulze var del af en trend, som har fået mange til at tale om 'Ostalgie', ${ }^{15}$ men som snarere må forståes som forsøget på at fastholde genforeningens psyki- 
ske og kulturelle problemer i deres sammenhæng. Richter er den hidtil sidste af mange fremstillinger i fiktiv eller reportageagtig form af østtysk opvoksede unge menneskers møde med vesten. Erindringens bevægelse tilbage til det gamle DDR tjener her prospektive mål: hvordan skal man leve i dette forenede land. Hovedparten af Richters bog skildrer, hvor de østtyske livs- og tankevaner støder sammen med livsformerne i Tysklands mest dynamiske og progressive by, Hamburg. En moderne udgave af en gammel topos i den europæiske kulturhistorie: den primitive vilde, der kommer til den kapitalistiske storby og udsættes for chokket. Her fortalt af ham selv. Til sidst finder Richter dog i Berlin ansatser til en tro på, at det, der hører sammen, også faktisk kan vokse sammen. Der synes at være sket noget, siden Fonty forlod byen i begyndelsen af I990'erne.

Alligevel kan man stadig finde problematikken fra Ein weites Feld i den aktuelle tyske diskussion. To unge, kvindelige forfattere har her placeret sig centralt, på en måde repræsenterer deres bøger hver sin side af Fontys valg. Jana Hensels Zonenkinder blev hurtigt efter at den var udkommet i september 2002 og havde fået positive, men også lidt forbeholdne anmeldelser i alle dele af Tyskland, en kultbog i den østlige del. Hensel er født i 1976 i Leipzig og blev som trettenårig af sin mor slæbt med til mandagsdemonstrationerne i oktober-november 1989. Siden blev hun hvirvlet ind i omvæltningerne efter $\mathrm{Mu}-$ rens fald med hvad dertil hørte af nye produkter, nye omgangsformer og nye signaler i den ungdomskultur, som hun og hendes kammerater med energi gik i gang med at tilegne sig. På det tidspunkt efter århundredeskiftet, hvor hun sætter sig ned og begynder at skrive denne erindringsbog, føler hun, at DDR er på vej til at fortone sig i bakspejlet. "Helt sådan som hele vort land har ønsket sig det er intet blevet tilbage af vores barndom, og pludselig opdager jeg, nu vi er blevet vokse og det næsten er for sent, alle de tabte erindringer" ${ }^{16}$ Det er lige før døren lukker sig, skriver Hensel et andet sted; hun fortæller sine erindringer $i$ en ganske let anspændt katastrofestemning: Det er i sidste øjeblik!

Det er denne tone og så det lille 'vi', der gemte sig i ovenstående citat og som er den gennemgående identifikationsmarkør i Hensels tekst, der udløste den store debat. På den ene side vakte det jubel blandt østtyske unge, der var vokset op i DDR, at deres erindringer blev taget alvorligt. Det for mange $i$ vesten provokerende ved disse erindringer var, at de ikke fremstillede livet i DDR som et helvede, men et sted, hvor man i mange henseender kunne have en god og tryg barndom. En generation, der fandt det spændende og i orden, at Muren faldt, havde også fundet det o.k. at vokse op i DDR. Livet i DDR fremstår ikke i Hensels bog som idyl, og de latterlige og ydmygende forhold, som også børn måtte underkaste sig: faneappeller, afliring af hyldester til Sovjetunionen, tvangsudskrivning til fritidsarbejde, etc., etc. bliver skildret uden sminke. Men Hensels barndom var almindelig som i vesten, og den verden hun tilpassede sig var sammenhængende og på sine egne præmisser logisk. Man kunne være der. Det er budskabet i Zonenkinder.

Debatten om bogen har været heftig og peger på, at spørgsmålet om en østtysk identitet så at sige post festum er et påtrængende tema for den moderne tyske identitetsbevidsthed. ${ }^{17}$ Blandt andet har man læst den som et modspil til Florian Illies' bog om den vesttyske firserungdom, Generation Golf fra 2000, som Jana Hensel $\mathrm{i}$ øvrigt har lånt adskillige retoriske greb fra (bl.a. det famøse 'vi'). Hvor Illies skildrer en vare- og oplevelsesdyrkende ungdoms orienteringsløshed, er det netop søgningen efter en kulturel rod og et geografisk sted, der virker stærkt i Hensels bog. Bagsiden er den tone af let vemod og sorg over tabet af barndommens "Geborgerheit", der til tider hviler over Hensels skildringer. Der kan være en smule af stemningen fra Walter Benjamins Berliner Kindheit over hendes Leipziger barndom: som hans flyver også hendes fremskridtsengel med ansigtet vendt bagud!

Nostalgi er der derimod bestemt ikke over Claudia Ruschs' Meine freie deutsche Jugend fra 2003, som man godt kan se som et svar på Hensels erindringsbog. Ruschs' forældre tilhørte inderkredsen i det oppositionelle DDR omkring fysikeren og forfatteren Robert Haveman og hans kone Katja, og Claudia (f. I97I) voksede op med drømmen om et andet og bedre DDR. Det er denne bevidsthed om at være 
anderledes og alligevel en vigtig del af DDR's identitet, der er den gennemgående tråd i Claudia Rusch' erindringer, der er formet som 27 små tekster, alle med en anekdotisk, politisk eller psykologisk perspektivrig pointe som slutning. Hvor Jana Hensel har som formål at få de ungdommelige hverdagserfaringer med DDR-regimet taget alvorligt, vil Claudia Rusch noget mere direkte politisk: Hun vil have sig selv og sine ligesindede anderkendt som ægte og legitime DDR-borgere - post festum, hvis man kan bruge denne betegnelse om et diktatur.

Tilspidset formuleres denne intention i det kapitel, hvor Claudi beretter om, hvordan hun og en kammerat Robert holder talen for dimmitenderne ved afslutningen af gymnasiet i sommeren 1990, tre måneder før DDR endeligt opløstes:

Tre måneder før alt opløstes for altid, påtog vi os alligevel den identitet, som vi så kraftigt havde afvist. $V i$ var også DDR. Ikke kun spioner og karrierister levede her, det gjorde også vores familier og venner. Ikke kun dem, der ville presse os ind i deres skema, var en del af dette land, men også dem, der havde gjort os til vågne hoveder. Kort før porten lukkede blev Robert og jeg statsborgere i DDR. ${ }^{18}$

Derfor er det også en af Claudias mest traumatiske oplevelser, da hun efter Murens fald skal forklare sine forældre, at hun under alle omstændigheder ville have forladt dette land - også hvis Muren havde bestået mange år endnu. Hun havde ikke som dem været parat til at påtage sig byrden ved at blive og kæmpe for et demokratisk DDR. Hvad de i øvrigt til hendes overraskelse og lettelse efterlods godt kan forstå og tilkendegiver, at de har regnet med. Claudia er på den måde, som hun selv beskriver det, den sidste ægte østtysker - og den første nye vesttysker (jfr. p. IоI). Som de sidste tænker hun først og fremmest på sin egen lykke og karriere. Samtidig med at hun bekender sig til en modstandsmoral, er Meine freie deutsche Jugend et selvopgør og et selvforsvar.

I den sammenhæng tiltager bogen igennem skildringerne af noget, man godt kan kalde hendes 'Wahlvaterland', Frankrig, hvor hun nok kan møde lidt katolsk puritanisme, men også en glød og spontan menneskelighed, der helt vælter hende over ende. Som for Fonty er Frankrig for Claudia forbundet med venskab, frihed og åndrighed. Den allersidste vignet $i$ bogen er af en hasarderet, men vellykket biltur gennem Paris' trafikkaos: først efter denne svendeprøve er Claudia blevet voksen og har tilegnet sig den store verden, som hun hele sit liv har drømt om. Den civilcourage, som var hendes baggrund i den østtyske opposition, udløses her i en suveræn beherskelses af den vestlige verdens (kulturelle) færdselsregler. Men det kritiske potentiale er gået tabt: her er ingen politisk brod mod bilismen og storkapitalismen, kun glæden ved at have tilegnet sig systemet og den store verden. Som Fonty - lidt vemodigt - skrev i sit sidste postkort fra Frankrig: "Jeg kan [...] ane, at historien snart ikke er længere". Han var kommet 'hjem' $i$ et fremmed land, tilfreds med at overlade fremtiden til sit revolutionære barnebarn. Unge Claudia Rusch skylder os en fortsættelse på sin historie om flugten til Frankrig. Men den kommer måske.

\section{Hjem uden hjemstavn}

Fælles for disse eksempler fra den nyere tyske litteratur er, at 'hjem'ı er noget man skal opsøge, konstruere, danne. Det er ikke bare givet. Med Murens fald forsvandt noget, man kunne leve i (selv om det var besværligt og ofte ydmygende), og man blev så at sige 'eksileret' ind i et land, man ikke havde valgt. Eksil er, skriver Bernhard Schlink i det nævnte essay, følelsen af at leve et sted og på en måde, der er fremmed for én, og som man ikke har indflydelse på: "Eksil er en metafor for erfaringen af fremmedgørelse". ${ }^{20}$ Også hvis man lever i et etnisk mindretal, tilhører et undertrykt køn, race, etc. Er man fysisk fordrevet fra et oprindeligt hjemsted, er det simpelt at forstå sit 'Heimat' som det tabte land, man ønsker sig tilbage til. Sværere er det at danne sig det til det eksistentielle eksil svarende forestilling om et 'hjem'. For man bor måske det sted, man altid har boet, eller også ønsker man sig bestemt ikke tilbage til det gamle land. 'Heimat' bliver derfor noget utopisk, sådan som det egentlig altid har været det i tysk litteratur, viser Schlink: "noget der ikke er opfyldt, noget uopfyldeligt", "håb. længsel og drøm”. ${ }^{21}$ Hjemstedet bliver et ikke-sted, et oi-topos, 
udstyret med alle de menneskelige egenskaber, det virkelige land ikke har. Den region, som tyskere til alle tider har været tilbøjelige til at foretrække frem for det store, fremmedgørende og undertrykkende Tyskland, er i virkeligheden også en konstruktion, hævder Schlink. Det er en tradition i tysk litteratur, at regionen er blevet fremstillet som en reaktion på den tyske fremmedgørelse - og derefter selv blevet oplevet som 'fremmed': "I uniformiseringen og anonymiseringen af livsomstændighederne bliver fremmedgørelsen konkret og stedbundet erfaret". ${ }^{22}$ Hvor skal det moderne (tyske) menneske i dag finde sit 'sted'?, spørger Schlink - næsten fortvivlet.

Foruden at være en betydelig forfatter er Bernhard Schlink jurist, professor i retsvidenskab ved Humboldt Universität i Berlin. Hans essay løber derfor ganske naturligt ud i nogle overvejelser over forholdet mellem hjem-følelse og menneskerettigheder. 'Hjem' er der, hvor man har disse rettigheder - "irgendwo" som han afværgende tilføjer. ${ }^{23}$ Fra den specifikt tyske problemstilling om stedet er han gledet over i det almene, sympatisk nok, men uden at man synes, han løser den første problemstilling. På en sær uerkendt måde gør han det, som de fleste af personerne i hans samling af fortællinger, Liebesfluchten fra 2000 gør: Han undviger. Stiller et for tysk identitetsbevidsthed centralt spørgsmål og flygter ud i det abstrakte, men derfor også lidt uforpligtende. “Tyskland: jamen, hvor ligger det?”, spurgte Goethe og Schiller i en af deres Xenien fra 1796.24 "Jeg finder ikke landet. Hvor lærdommen begynder, hører det politiske op". Den tyske misère, kaldte Marx det: at forestille sig i tanken, hvad man ikke mente at kunne finde i det reale.

Herom handler også et af hovedværkerne i ny tysk litteratur. Hans-Ullrich Treichel er født og opvokset i Emsland, egnen sydvest for Bremen, men er i dag leder af den tyske forfatterskole, Litteraturinstituttet i Leipzig, hvor han i rigt mål har øst-vestproblemstillingen inde på livet. Hans Tristanakkord fra 2000 stiller dog spørgsmålet om forholdet mellem det lokale og det globale som et alment tysk fænomen - og som et alment menneskeligt. Det er en righoldig bog, hvoraf her kun et enkelt aspekt kan trækkes frem.
Hovedpersonen Georg er uddannet germanist og har fusket lidt med at skrive digte, og da han tilfældigt har fået stilling som sekretær for den verdensberømte komponist Bergmann og denne står og mangler en hymne til et korværk, han vil skabe, får Georg til opgave at skrive denne hymnes tekst. Det skal være en hymne i en splittet tid, forklarer Bergmann, også lidt anakronistisk, en blanding af Hölderlin og noget moderne:

"En Hölderlin", sagde Bergmann, "der nok vandrer rundt i Schwaben, men samtidig har et penthouse i New York. Det behøver selvfølgelig ikke nødvendigvis at være et penthouse, det kan også være en lille lejlighed i Greenwich Village eller for min skyld i Dumbo... New York og Nürtingen", sagde Bergmann, “så ved De, hvad jeg mener". Georg var ikke sikker på, at han vidste, hvad Bergmann mente, men for en sikkerheds skyld sagde han i første omgang ingenting. Og så tilføjede Bergmann: "Under ingen omstændigheder Stuttgart". ${ }^{25}$

Kosmopolitten Bergmann vil have sin tyske hjemegn trukket med ind i sit globale værk; han lever overalt: på Hebriderne, i New York, på Sicilien, men alle steder finder han - og Georg - sporene fra deres tyske region, floden, træerne, mosset. De er aldrig 'hjemmefra', kan ikke glemme udgangspunktet, skønt Bergmann er tilbøjelig til at glemme alle detaljer i livet omkring ham, og Georg skriver ph.d.-afhandling om glemsel, men uden rigtig at kunne komme på sporet af noget materiale. Om han ender med at få skrevet den Hölderlinske Nürtingen/New York hymne, står ved romanens slutning uafklaret: en tristanakkord er i den Wagnerske musik en akkord, der består af så mange forskellige tonale elementer, at man ikke med sikkerhed kan sige, hvordan den skal opløses. Derfor forbliver den uafsluttet, hænger så at sige i luften ved musikkens ophør, indikerende at fortsættelse følger. "Det er en længere historie”, ville Fonty have sagt.

Treichels bog samler under alle omstændigheder i sit spillende prisme et vigtigt tema i ny tysk litteratur. Den viser - som i øvrigt også Treichels sidste roman, Der irdische Amor fra 2003 - den tyske identitet udspændt mellem en regional rodfæstethed og global kosmopolisme. Dahin! dahin! gælder nu ikke længere 
som i Goethes Wilhelm Meister blot citronernes land, selv om Italien stadig er en vigig metafor for den tyske hjemstavns 'andet', men har sit sted overalt på kloden. Hos Felicitas Hoppe, Zoë Jenny, Christian Kracht, Christoph Peters, Judith Hermann, Andreas Maier, Urs Faes og Patrick Roth, for blot at nævne nogle få, længes personerne ud mod det forjættede blå - for dér at blive kastet tilbage til det oprindelige sted, hvor de konstaterer, at det aldrig har eksisteret andre steder end i deres egen imagination. Hvad der er kommet til siden Goethe, er samfærdselsmidlernes udvikling, problemstillingen er den samme.

\section{Vandringer fra Mark Brandenburg}

Og selv rejsens art og tempo har ikke altid ændret sig. Vandrebevægelsen har altid været overordentlig stærk i Tyskland, og vandretemaet står mere centralt i tysk litteratur end i andre litteraturer, jeg kender til. Fra Tiecks romantiske Franz Sternbalds Wanderungen (I798) over Fontanes nævnte vandringer i Mark Brandenburg til W.G. Sebalds fodrejse gennem Suffolk i Saturns ringe (1998) har vandringen ud i naturen haft en civilisationskritisk funktion, beskrevet en gendannelse af det hele menneske $i$ vandringens synkronisering af krops- og tankebevægelse.Vandring er den tyske form for meditation. At så forskellige former for 'Wandervogel'-organisationer har haft tvivlsomme politiske observanser, er en anden sag. Hitler Jugend misbrugte så mange positive traditioner.

I ny tysk litteratur har vi imidlertid (i alt fald) to eksempler på, at vandretemaet udnyttes $\mathrm{i}$ forsøget på at bestemme Tyskland mellem det regionale og det globale. Lad mig slutte denne lille introduktion med at nævne dem. F.C. Delius' Der Spaziergang von Rostock nach Syrakus fra $1995^{26}$ handler om tjeneren Paul Gompitz, der bor og lever i DDR og er ganske godt tilfreds med det - bortset fra, at han har en drøm om at gentage sin helt, den romantiske eventyrer og skønånd, Johan Gottfried Seumes fodrejse fra Rostock til Syracus på Sicilien. Og det kunne man jo ikke sådan uden videre i det gamle DDR, så han arbejder næsten ti år på at konstruere en båd, så han kan flygte fra Rostock til Gedser og derefter til fods bevæge sig til Sicilien. Hans højeste mål er at realisere sin drøm og vende tilbage til DDR, der derefter vil være hans idealland at bo i. Det lykkes ham mirakuløst at gennemføre projektet og så efter en kort fængselsstraf for republikflugt at blive lukket ind i DDR igen. Men handlingen har da bevæget sig op til foråret 1989, og læseren ved, at DDR kort tid efter ville forsvinde fra jordens overflade. Utopien om at kunne forene det trygge, borgerlige DDR med drømmen om den fantastiske verden viser sig at være en illusion, men en drøm der har bevæget Gompitz til den mest fantastiske opfindsomhed og lært ham, at forskellen mellem ude og hjemme måske ikke er så stor, som han gik og troede i sit socialistiske fængsel.

På den måde handler Delius' fodrejse også om DDR dengang og nu: længslen efter at komme ud og længslen efter at komme hjem som to sider af den samme sag. Det tyske dilemma gennemspilles af Seume i 1802 og Gompiz i 1989 mutatis mutandis. I sommeren og efteråret $200 \mathrm{I}$ gennemførte endnu en tysker en fodrejse, denne gang fra Berlin til Moskva. Wolfgang Büscher hedder han, er journalist ved den berlinske avis "Die Welt", og beretningen om turen: Berlin-Moskau. Eine Reise zu Fuss udkom i 2003 og fik den fornemme Kurt Tucholsky-pris. ${ }^{27}$ Büscher gik den klassiske 'hærvej', som polakker, franskmænd og sidst Hitlers tropper i I94I havde gået, alle for senere at blive drevet den modsatte vej af russerne. Det er da også først og fremmest sporene af det tyske forhold til det østlige, som Büscher opsøger, herunder overlevende fra russernes driven tyskerne tilbage til Berlin. Det er en historie om at møde det fremmede og forfærdelige dér ude, hvad enten det er 'zonen' omkring Tjernobyl, skoven hvor Stalin lod tusinder af polske officerer likvidere eller den uhyggelige og uvirkelige iagttagelse $i$ et fjernsyn $i$ den hviderussiske by Vitebsk af terrorangrebet på World Trade Center. Men Büscher møder også historierne om krigens forunderlige mirakler, om menneskelighed og kærlighed, der bærer igennem rædslerne. Beretningens scoop er den minutiøse skildring af den gåendes fysiske og psykiske nedslidning under de 82 dages vandring, en hudløshed der gør de dramatiske og til tider patetiske fortællinger troværdige. Vandringens rytme udløser de slyngede og digrederende historier, som Büscher graver op af jorden som en 
anden arkæolog: “østpå er alt en historiegrav, tragediens åbne grube, stoffet ligger lige under græsset, det er virkelig råt, ubearbejdet, uslebet. I sin amoralske skønhed har det mere lighed med bizarre sagn end med de opbyggelige fabler, som favoriseres af en tid, der tørster efter moral". ${ }^{28}$ Nedsmeltningen til kroppens elementære rytme er også nedsmeltningen til den rene beretning: stedet samler fortid og nutid i den samme sproglige bevægelse.

Men stedet åbner også for tid og forandring. Det første historiske sted, Büscher dvæler, er Seelowhøjene øst for Berlin, hvor resterne af den tyske hær forsøgte at stoppe de fremrykkende russere $\mathrm{i}$ april I945. Her forestiller han sig en tysk soldat, som han kan identificere sig med: en ung gymnasiast, der midt i ragnarokket klamrer sig til sin Faust og sit udvalg af Goethes digte: "og du klamrer dig til det eneste, du har tilbage, og det er nu skole-Goethe, og du reciterer med rystende kæber 'Påskespadsereturen' her i det blodige mudder, og omkring dig sprøjter det med skudsalver, og granater slår ned og så videre — ". ${ }^{29}$ Ved sin rejses begyndelse signalerer Büscher, at han godt kender sin genres historie: vandrertraditionen i tysk litteratur. Han har det klassiske, kulturelle Tyskland med sig.

Og det er da også det, han finder for enden af sin rejse, ikke i selve Moskva, men lige uden for. Han har på turen ind til den russiske hovedstad skyndt sig forbi Peredelkino, hvor Pasternak boede i sovjettiden, og hvor han skrev sin Doktor Zivago. Efter et par dage med russiske venner i Moskva fortryder Büscher og tager alligevel bussen ud til Peredelkino. Og herude finder han igen og for sidste gang Tyskland, sit eget Tyskland og derfor sig selv. Han finder i Pasternaks hjem det digt, denne skrev om sit studieophold i Marburg, og mindes i et pludseligt syn sit eget studieophold i Marburg:

Noget brød frem i dette øjeblik, jeg så de samme spidse tage, de samme haver og vinterhaver, de samme skæve bindingsværksfacader. De krogede stræder,jeg engang havde været fortrolig med, de gamle professorvillaer på skrænten, modbilledet til steppens verden, snørkler og kvaster på den vældige brede eurasiske divan. Hvorfor stod jeg her i hans hus? For at blive mindet om, hvorfra jeg kom. ${ }^{30}$
Han forlader derefter hurtigt huset, og bogen slutter.

\section{Tyskland bl.a.}

Nürtingen/New York - Marburg/Moskva: at finde det hjemlige i det fremmede, at opdage at vejen til Tyskland går via den store verden. Jeg siger ikke, at al ny tysk litteratur handler om det. Men megen gør. Fontys valg har vist sig ikke at være et valg, man som tysker behøver at tage: Man kan både få sin tyske egn og sin globale verden. Et forenet Tyskland er ikke farligt, for selv om det er stort, er det lille i forhold til den store verden. Den typiske 'helt' eller 'heltinde' i moderne tysk litteratur er beskeden og pragmatisk. Man tumler derudaf og kommer ofte galt af sted; man mislykkes, benytter sig af tvivlsomme metoder, men man klarer sig. 'Deutschland über alles' er blevet til 'Deutschland unter anderm' ${ }^{1}$, indfoldet med sit eget særpræg i den globale verden. Sådan som også Fonty havde en drøm om, at det kunne ske.

Mange hovedpersoner i ny tysk litteratur ligner ham af væsen og tankegang. Men de vælger anderledes.

\section{Noter}

I. Se Ulrich Beck: Was ist Globalisierung?, Frankfurt/M 1997 og Ulrich Beck (Hrg.): Politik der Globalisierung, Frankfurt/M 1998.

2. Så sent som i 1987 udkommer f.eks. en af Albrecht Weber redigeret Handbuch der Literatur in Bayern, og vi finder så sent som i 1970'erne fremstillinger af hessisk og rheinland-pfalz'sk litteratur.

3. Se f.eks. "Kurze Rede eines vaterlandslosen Gesellen" in Die Zeit 9/2 1990, optaget i Ein Schnäppchen namens $D D R$, 2. oplag, München I999.

4. Günter Grass: En langere historie, oversat af Per Øhrgaard, Kbh. 1996, p. 335 .

5. Ibid., p. 42.

6. Ibid., p. 338.

7. Ibid., p. 502.

8. Bernhard Schlink: Heimat als Utopie, Frankfurt/M 200o,

p. I5-I6.

9. Ibid. p. I4.

Io. Peter Richter: Blühende Landschaften. Eine Heimatkunde,

München 2004, p. 20.

II. Ibid.

I2.Ibid. p. Iо. 
I3.Ibid. p. 197 .

I4.I august 1999 oplevede jeg dem træde sammen ind i rådhussalen i Århus: Grass forrest, stolt piberygende, selvsikker, vis på at Nobelprisen ventede for Mein Jahrhundert. Schulze bagerst, duknakket, ydmyg, hyldet genert i sit lange hår. Alle var kommet for at høre Grass, men mange blev fascineret af Schulze.

I5.F.eks. i forbindelse med Wolfgang Beckers film Good Bye, Lenin og Hans Pleschinskis erindringsbog Ostsucht, begge fra 2003. Begge forsøger på grundlag af erindringer om det svundne land at udvikle utopiske forestillinger om et andet livsgrundlag. Men om egentlig længsel tilbage kan man vel næppe tale. Diskussionen af det interessante begreb 'Ostalgie' ligger dog uden for mit ærinde i denne artikel.

I6.Jana Hensel: Zonenkinder, Reinbek 2002, p. I4 (dansk oversættelse 2004).

I7. Meget af debatten er samlet i Tom Kraushaar (hrg.): Die Zonenkinder und wir. Die Geschichte eines Phänomens, Hamburg 2004.

I8. Claudia Rusch: Meine freie deutsche Jugend, Frankfurt/M, 2003, p. IOO (mo).

I9.Det tyske ord 'Heimat' ligger, så vidt jeg kan fornemme, stilmæssigt et sted mellem det danske, neutrale ord 'hjem' og det mere ideologisk ladede 'hjemstavn'. Jeg foretræk- ker af flere grunde det første.

20.Bernhard Schlink, Heimat als Utopie, p. I2.

2I. Ibid., p. 26-27.

22.Ibid., p. 2 I.

23. Ibid., p. 45 .

24.Goethe: Sämtliche Werke, bd. 4, Stuttgart I9I2, p. I65. Xenien er en samling af epigrammer og aforismer, der kontinuerligt efterspørger de tyske landsdeles særlige karakteregenskaber. Men et samlet Tyskland kan de to olympere ikke forestille sig: "Zur Nation euch zu bilden, ihr hoffet es, Deutsche, vergebens; Bildet, ihr könnt es, dafür freier zu Menschen euch aus" (ibid.).

25. Hans-Ullrich Treichel: Tristanakkord, oversat af Anneli Høier, Kbh. 200I, p. I00-IоI.

26. Oversat til dansk af Niels Brunse 1997 til En fodrejse fra Rostock til Syracus.

27. Dansk oversættelse ved Hanne Lund: Berlin-Moskva. En rejse til fods, Kbh. 2005.

28.op. cit., p. IOI.

29. op. cit., p. I5.

30.op. cit., p. 198.

3I. Titlen på Hans Magnus Enzensbergers essaysamling fra I967. 